\title{
Recent advancements in the hormonal stimulation of ovulation in swine
}

This article was published in the following Dove Press journal:

Veterinary Medicine: Research and Reports

5 October 2015

Number of times this article has been viewed

\author{
Robert V Knox \\ Department of Animal Sciences, \\ 360 Animal Sciences Laboratory, \\ University of Illinois, Champaign \\ Urbana, IL, USA
}

Correspondence: Robert $\mathrm{V}$ Knox Department of Animal Sciences, 360 Animal Sciences Laboratory, University of Illinois, 1207 West Gregory Drive, MC-630, Champaign Urbana, IL 6I80I, USA

$\mathrm{Tel}+\mathrm{I} 2172445177$

$\mathrm{Fax}+\mathrm{I} 2173338286$

Email rknox@illinois.edu

\begin{abstract}
Induction of ovulation for controlled breeding is available for use around the world, and conditions for practical application appear promising. Many of the hormones available, such as human chorionic gonadotropin (hCG), gonadotropin-releasing hormone $(\mathrm{GnRH})$ and its analogs, as well as porcine luteinizing hormone ( $\mathrm{pLH}$ ), have been shown to be effective for advancing or synchronizing ovulation in gilts and weaned sows. Each of the hormones has unique attributes with respect to the physiology of its actions, how it is administered, its efficacy, and approval for use. The timing for induction of ovulation during the follicle phase is critical as follicle maturity changes over time, and the success of the response is determined by the stage of follicle development. Female fertility is also a primary factor affecting the success of ovulation induction and fixed time insemination protocols. Approximately $80 \%-90 \%$ of female pigs will develop mature follicles following weaning in sows and synchronization of estrus in gilts. However, those gilts and sows with follicles that are less developed and mature, or those that develop with abnormalities, will not respond to an ovulatory surge of LH. To address this problem, some protocols induce follicle development in all females, which can improve the overall reliability of the ovulation response. Control of ovulation is practical for use with fixed time artificial insemination and should prove highly advantageous for low-dose and single-service artificial insemination and for use with frozen-thawed and sex-sorted sperm.
\end{abstract}

Keywords: artificial insemination, follicle, hormone, ovulation, swine

\section{Introduction}

Induced ovulation is of great interest for the commercial swine industry. It is a technology that can help capture increased genetic gains and improve pig production efficiency through use of single sire insemination and optimal time of insemination. Additionally, it can serve as a gateway technology for use of cryopreserved boar sperm, sex-sorted semen, and low-dose, single-service artificial insemination (AI). Methodology for hormonal control of ovulation has been available for the past 60 years with application in pigs, humans, rodents, cattle, rabbits, dogs, and birds. ${ }^{1-14}$ Many species of mammals and birds, whether spontaneous or induced ovulators, can respond to exogenous hormones for controlled ovulation. For many years, induction of ovulation has been performed using highly purified human chorionic gonadotropin (hCG), partially purified pituitary isolates (follicle-stimulating hormone $[\mathrm{FSH}]$ and luteinizing hormone $[\mathrm{LH}]$ ), and synthetic gonadotropin-releasing hormone $(\mathrm{GnRH})$ and $\mathrm{GnRH}$ analogs. In pigs, the approach used for ovulation induction has varied depending upon the maturity of the animal and whether synchronization of follicle development was applied. Ovulation induction has been used to study the physiology of ovulation, oocyte maturation, 
fertilization, embryo development and survival, as well as determining the impact of AI timing in relation to ovulation. Ovulation is a highly regulated process, and it is important to consider that approaches for its control could influence processes related to follicle and ova maturation, ovulation and formation of the corpus luteum, fertilization ability of sperm and eggs, and embryo development and survival.

\section{Physiology and endocrinology of follicle development and ovulation in pigs}

In the pig, the process of follicle development is controlled to regulate the timing and the number of follicles that reach maturity in order to ovulate the proper number of eggs. In maturing females, primordial follicles leave the resting pool and develop to the antral stage, where they become dependent upon FSH for their continued growth and survival. The recruited follicles may continue to mature or could undergo atresia at any stage as a result of granulosa cell apoptosis. ${ }^{15}$ The follicles that continue to mature become visible on the surface of the ovary when they reach $\sim 1 \mathrm{~mm}$ in size. Follicle maturation models are complex and have been reported in the pig based on follicle size, hormone binding, and steroid activity. ${ }^{16} \mathrm{FSH}$ binding and receptors predominate in pig follicles that are small to medium sized $(1-5 \mathrm{~mm})$ but decline as follicles mature to the larger ovulatory size during the follicle phase. Small follicles bind predominantly FSH and show maximal FSH receptor gene expression, while binding minimal $\mathrm{LH}$ and showing no detectable $\mathrm{LH}$ receptor expression. Medium-sized follicles can bind both FSH and LH, and expresses the genes for each type of receptor. In large follicles, LH binding and receptor gene expression is high, while FSH binding is minimal and FSH receptor gene expression is not detectable. ${ }^{17,18}$ In the pig, except during the follicle phase, maximum follicle size remains below $6.0 \mathrm{~mm}$, which is known as the small- to medium-sized class of follicles. At the start of the follicle phase, a cohort of 40-100 surface follicles $<3$ and 3-6.4 mm (medium) in diameter may be present (Figure 1). From the medium-sized pool of follicles, a cohort is selected to grow and mature. The selected follicles likely vary slightly in size, although this has not been proven clearly. At the start of the follicle phase, FSH is elevated for 24-36 hours before declining. The decline in FSH is due to follicle production of inhibin, a protein dimer that acts at the pituitary to suppress FSH release. ${ }^{19-22}$ The selected follicles mature in size with an expanding fluid antrum. The granulosa and theca cell layers divide and are active in steroid production. Ovulatory sized follicles, or those follicles that are most often counted and measured at estrus, are typically between 6 and $12 \mathrm{~mm}$, depending upon whether they are measured by ultrasound $(6-8 \mathrm{~mm})$ or by physical measurement $(8-12 \mathrm{~mm})$. There is evidence that not all follicles at estrus are the same size. ${ }^{23-25}$ This is interesting and may be normal to some extent within a narrow size window, but may not be optimal for fertility. The noted differences in ovulatory follicle sizes may result from factors that cause differences in follicle selection and maturation. These may include negative energy balance, stress, lactation length, and season. Heterogeneity in ovulatory follicles may result in variation in oocyte maturity, follicle response to the LH surge, and lead to reduced fertilization rates, poor embryo survival, cystic follicle development, and poorly formed corpora lutea. During a follicle phase in weaned sows and mature gilts, ovulatory sized follicles develop during a 5 to 7 day period, and, as the follicles mature, the granulosa cells express aromatase ${ }^{17}$ and become highly efficient in the conversion of steroid precursors to estrogen. ${ }^{26}$ Estrogen produced by the follicles enters into the blood stream and acts at the level of the hypothalamus and pituitary to regulate GnRH release and the gonadotropin surge.

\section{Control of $\mathrm{GnRH}$ release}

Positive feedback of estradiol at the level of the hypothalamicpituitary axis is the key factor that initiates the ovulatory $\mathrm{LH}$ surge and the process of ovulation. In humans, estrogen has been shown to have positive feedback effects on specific kisspeptin neurons that regulate $\mathrm{GnRH}$ release. ${ }^{27}$ Although not all species respond similarly, in the pig, estrogen acts at the central nervous system to modulate GnRH. ${ }^{28}$ Administration of estrogen has been shown to induce the LH surge, but initially induces a temporary LH decline, ${ }^{29}$ which is thought to be important for allowing the pituitary to build up LH stores, for surge release 24-48 hours later. In pigs, estrogen is known to modulate $\mathrm{GnRH}$ release to alter gonadotropin release, and stalk-transected animals given GnRH show no modulation of the gonadotropins by steroids. ${ }^{30}$ Arrays of neurons that synapse in the hypothalamus function to regulate the release of neuropeptides and GnRH. ${ }^{30}$ The hypothalamus is able to integrate endogenous and exogenous signals to control reproduction through GnRH. Kisspeptin has been identified in several species as a neuropeptide secreted by hypothalamic neurons that induces GnRH release through neuron depolarization. ${ }^{31}$ Further, a kisspeptin family of regulatory peptides (10-54 amino acids) can bind to neuron receptors to regulate GnRH. Although not clear in the pig, numerous other vertebrate species have GnRH-inhibiting neurons and 


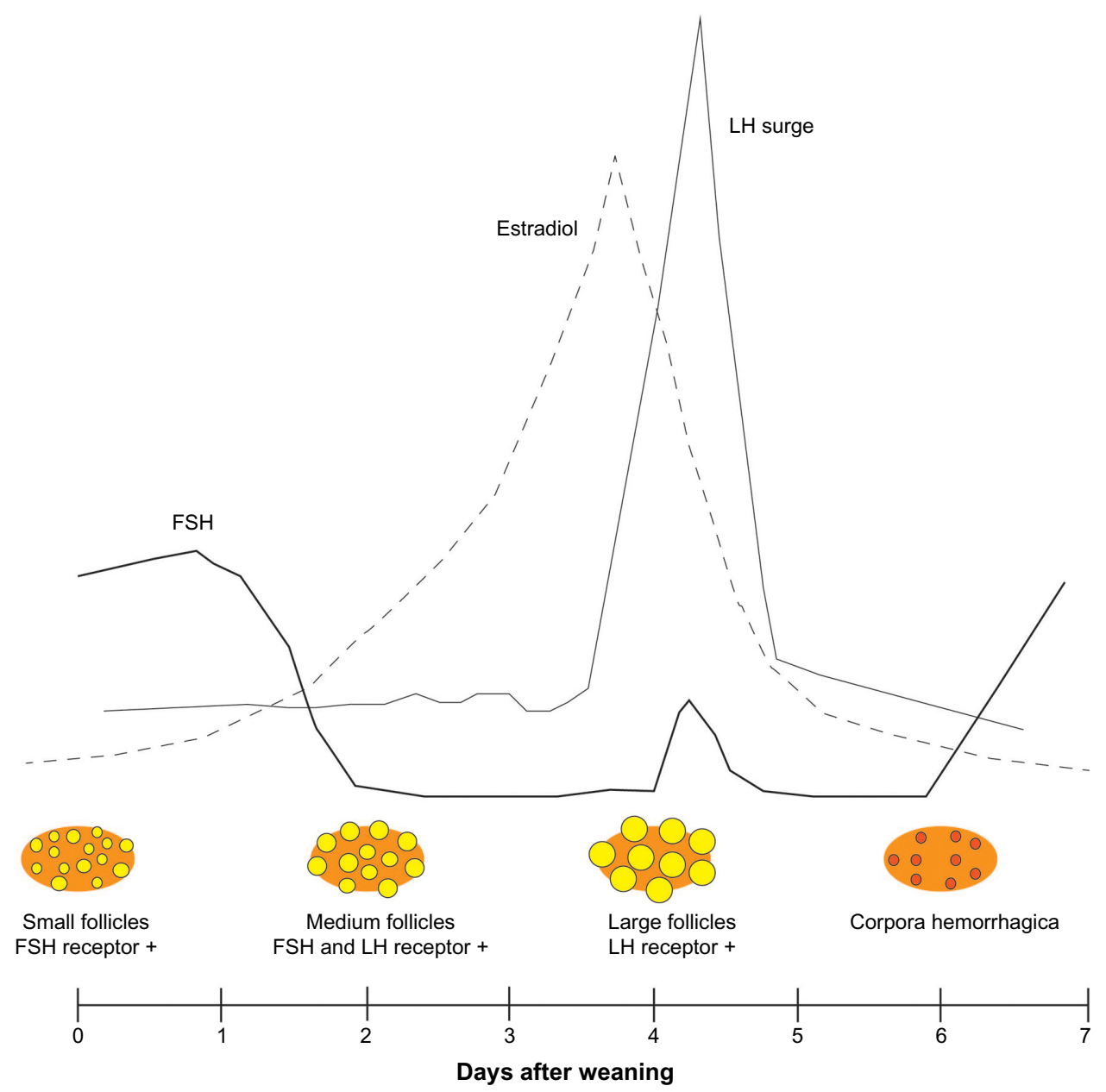

Figure I Illustration of follicle development and hormones in the weaned sow during the follicular phase showing small $(<3 \mathrm{~mm})$, medium $(3-6.4 \mathrm{~mm})$, and large $(>6.5 \mathrm{~mm})$ follicles and the dominant type of follicle hormone receptor.

Abbreviations: $\mathrm{FSH}$, follicle-stimulating hormone; $\mathrm{LH}$, luteinizing hormone.

hormones that act to inhibit neuron GnRH synthesis and release, and inhibit or regulate LH pulse amplitude from the pituitary. ${ }^{32}$ Exogenous kisspeptin given in bolus intravenous or subcutaneous injections has been shown to induce $\mathrm{LH}$ and FSH surge release in several species. ${ }^{33}$ In gilts, both low and high doses of kisspeptin administered by intracerebroventricular infusion cause an immediate surge release of LH, while FSH release occurred only at high doses. ${ }^{34}$ At this time, the ability of exogenous kisspeptin to directly induce ovulation through an LH surge has not been clearly demonstrated, but appears to be possible based on gonadotropin release patterns. ${ }^{33}$

\section{GnRH regulation of $\mathrm{LH}$ and $\mathrm{FSH}$}

$\mathrm{GnRH}$ is released in pulses of defined frequency and amplitude that are regulated by signals from internal and external cues. Ovarian feedback regulation of gonadotropin release can occur through regulation of gonadotroph $\mathrm{GnRH}$ receptors, neural release of kisspeptin or GnRH. Numbers of GnRH receptors on gonadotrophs change temporally relative to the LH surge. Pulses of GnRH enter into the hypophyseal portal vessels where it may bind pituitary gonadotroph cells to induce FSH and LH release. GnRH binds to GnRH receptor 1 on gonadotrophs by a G-protein coupled receptor, with ligand binding leading to activation of second messenger pathways (PLC, IP3, and DAG) that increase intracellular calcium, to initiate pathways such as ERK (extracellular signal-regulated kinase) that are linked to gonadotropin subunit gene transcription. ${ }^{35} \mathrm{GnRH}$ has a short half-life in circulation and is cleared within 4 minutes primarily by glomerular filtration and through peptidase degradation at the target cell. In the pig, GnRH is the primary factor regulating LH release, and is demonstrated by: 1) GnRH administration and LH release in a near 1:1 relationship, 2) absence of LH release in hypothalamic-pituitary axis stalk-transected animals, and 3) absence of LH release following passive immunization 
against GnRH. In contrast, GnRH administration and FSH do not show 1:1 pulses and stalk transection does not eliminate FSH release. ${ }^{30}$ LH surge release is also distinct from LH pulse release, as a surge can only be induced after a period of time following estrogen exposure in pigs. ${ }^{29}$ In pigs, the frequency of GnRH pulses affects the patterns of release for LH and FSH, with low-frequency GnRH pulses generating low-frequency LH pulses and elevated FSH, similar to that observed during the luteal phase. ${ }^{19,36,37}$ In contrast, highfrequency GnRH pulses increase the frequency of LH pulses and induce a surge release of $\mathrm{LH}$ and $\mathrm{FSH}$, similar to that observed during the follicle phase. Interestingly, the effect of high-frequency GnRH pulses on LH release diminishes over time and is thought to occur due to downregulation of its receptors since pools of LH in the gonadotrophs remain. ${ }^{37}$ The importance of GnRH pulsatile release is evident since continuous exposure of gonadotrophs to the same level of GnRH leads to downregulation of GnRH receptors. Further, the amplitude and the frequency of GnRH pulses have been shown to alter the synthesis of the $\alpha$ as well as each of the $\beta$ subunits for $\mathrm{LH}$ and $\mathrm{FSH}^{38}$

\section{The physiology of ovulation}

The process of ovulation is initiated soon after exposure of the follicle to the LH surge, and it quickly becomes independent of subsequent gonadotropin control. The surge initiates the processes for terminating follicle growth, resumption of meiosis, germinal vesicle breakdown, start of luteinization, and restructuring of the follicle wall. LH binds to plasma membrane receptors in follicular granulosa and theca cells through G-protein coupled receptors. ${ }^{39}$ The surge and start of ovulation are associated with increases in: inflammatory cytokines (IL-1 and TGF $\alpha$ ), COX-2, and prostaglandin, ${ }^{39}$ vascular pressure and permeability, and changes in collagen synthesis and breakdown. ${ }^{40}$ Rupture of the follicle and expulsion of the cumulus oocyte complex requires breakdown of the follicle wall, including the surface epithelium and collagen layers in the tunica albuginea and theca externa. For several hours after the LH surge, minimal modification of the follicle is evident, but with progression, changes are noted in follicle swelling, shape, and blood flow. The process of ovulation can be blocked by inhibitors of protein, steroid, or prostaglandin synthesis, indicating a complex sequence of events. Protein synthesis is essential for production of enzymes needed in the synthetic pathways involved in tissue remodeling and hormone production in the follicle. Steroid production in the follicle is also essential to ovulation in mice as increased progesterone production and progesterone receptors are observed following the LH surge. The LH released during the surge binds to its receptors on granulosa cells and induces an increase in progesterone receptors on the same cells within $4-8$ hours. ${ }^{41}$ The critical role of progesterone is demonstrated by inhibition of ovulation with RU-486, a progesterone receptor antagonist, and the observation that the progesterone receptor knockout mouse cannot ovulate, despite normal development of the oocyte and cumulus cells following the LH surge. ${ }^{42}$ Ovulation also depends on prostaglandin production through the inflammatory response, ${ }^{18}$ and blocking prostaglandin production by indomethacin prevents ovulation but not oocyte maturation, luteinization, or a rise in progesterone. The increase in prostaglandin following the LH surge induces plasminogen, matrix metalloproteinases, ADAMTS enzymes, collagenase, and other enzymes in the follicular cells that will act to degrade the follicle wall. ${ }^{43}$

A figure to help illustrate the relationship of reproductive hormones, estrus, and ovulation in pigs is shown in Figure 2, and utilizes profiles for estradiol, $\mathrm{LH}$, and progesterone from weaned sows, ${ }^{44} \mathrm{FSH}$ data based on estrus in mature gilts, ${ }^{36}$ and GnRH data from studies in ewes. ${ }^{45,46}$ In weaned sows that displayed estrus on day 4 , the average duration of estrus was $54 \pm 15$ hours and showed considerable variation in the interval from onset of estrus to the time of ovulation during estrus ( $54 \%-86 \%$ of the duration). In sows, the interval from the peak of estradiol to the onset of estrus averaged $3 \pm 11$ hours, the peak of estrogen to the peak of LH, $11 \pm 5$ hours, and the peak of estrogen to ovulation, $41 \pm 4$ hours. These data also reveal that the interval from onset of estrus to onset of the LH surge was $-5 \pm 10$ hours, onset of estrus to the LH peak was $8 \pm 11$ hours, onset of the LH surge to ovulation was $44 \pm 3$ hours, and peak of LH to ovulation $30 \pm 3$ hours. ${ }^{44}$ The duration of the LH surge has been reported to be $\sim 24$ hours, with noted variation in the timing of the surge in relation to the onset of detected estrus. ${ }^{47,48}$ Perhaps, variation in all measures for estrus and ovulation may be expected since variation in the symptoms and onset of estrus and estrus to ovulation have been reported. Variation in timing of ovulation might be associated with the extent of follicle heterogeneity, which has also been associated with oocyte and embryo diversity. ${ }^{49}$ Despite evidence of follicle heterogeneity, the duration of ovulation appears to vary little, lasting only $2-4$ hours in pigs, with the order of follicle ovulation not related to follicle size or associated with embryo diversity. ${ }^{50}$

\section{Induced follicle maturation}

A primary requirement for success in ovulation induction is the presence of mature follicles on the ovary that can respond 


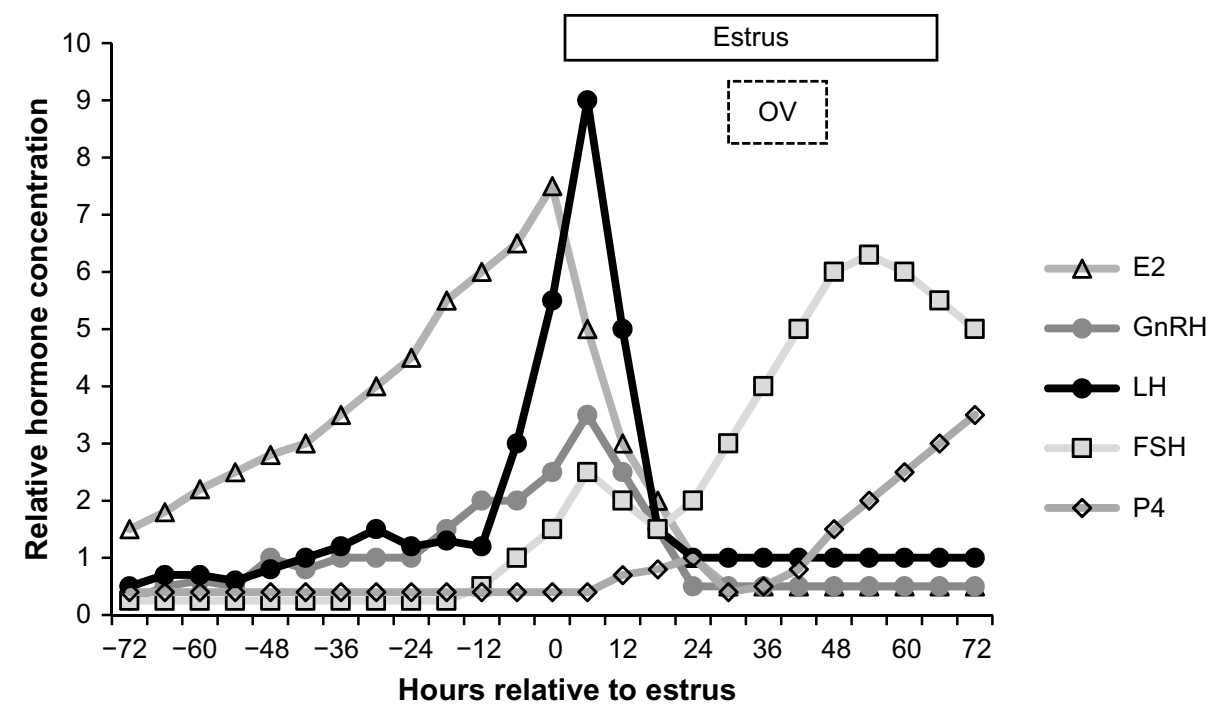

Figure 2 Representative hormonal profile of LH (ng/mL), FSH (ng/mL), estradiol ( $\mathrm{pg} / \mathrm{mL})$, progesterone $(\mathrm{ng} / \mathrm{mL})$, and $\mathrm{GnRH}(\mathrm{pg})$ during proestrus in relation to the timing of estrus and $\mathrm{OV}$ in the mature female pig.

Note: Data from Knox et al, ${ }^{36}$ Soede et al, ${ }^{44}$ Jonas et al, ${ }^{45}$ and Schillo et al. ${ }^{46}$

Abbreviations: LH, luteinizing hormone; FSH, follicle-stimulating hormone; GnRH, gonadotropin-releasing hormone; OV, ovulation; E2, Estradiol; P4, progesterone.

to an LH surge. Follicle maturation can be induced in prepubertal gilts, cyclic females, and lactating and weaned sows. Interest in these animals focused on synchronized breeding management and establishing pregnancy during lactation in sows. While in many cases of induction of estrus and ovulation, fertility is achieved following insemination, there are also cases of fertility failures that are associated with development of cystic follicles, lack of mature follicle growth, estrus expression, and conception. Failure to induce follicle development and estrus expression have been associated with the ratio of FSH:LH activity, the concentration of the hormones, and the duration of stimulation. In pigs, ovarian follicles that have reached a minimum stage of maturity $(\sim 6$ $\mathrm{mm}$ ) appear able to respond to hCG and form corpora lutea compared to less mature follicles ${ }^{51}$ and are $1-2 \mathrm{~mm}$ smaller than the average size of ovulatory follicles measured at estrus. ${ }^{23,52,53}$ The use of gonadotropins to mature follicles and induce estrus expression has been reported following use of hormones with predominantly FSH activity, and include equine chorionic gonadotropin (eCG),${ }^{54} \mathrm{eCG}$ with $\mathrm{hCG},{ }^{55}$ and partially purified $\mathrm{FSH} .{ }^{56}$ In pigs, $\mathrm{hCG}$ given to prepubertal gilts can induce ovulation but is much less effective for induction of estrus and suggests estrus and ovulation rely on follicle maturity, estrogen production, and feedback which requires some level of FSH support. ${ }^{57}$ In pigs, single injections of eCG with or without $\mathrm{hCG}$ induce follicle maturation and estrus expression within a 4- to 5-day period. As such, many ovulation induction protocols use follicle maturation using eCG. ${ }^{1,58-61}$ From a practical standpoint, eCG alone and $\mathrm{eCG}$ and $\mathrm{hCG}$ combinations require a single injection, and can induce estrus in $60 \%-70 \%$ of prepubertal gilts and improve estrus expression in weaned sows by $10 \%-15 \%$, depending upon parity, lactation length, and season. These hormones have been used for many years with great success and are approved in numerous countries around the world. Use of FSH and the natural form of GnRH can achieve a similar result, but due to their short half-lives, require multiple injections within a day for FSH and hourly injections for GnRH. Further, FSH is only partially purified from pituitary LH and can vary in bioactivity. Hourly injections of GnRH for 7 days was able to induce estrus and ovulation in prepubertal gilts, ${ }^{62}$ with the hourly pulses important in lactating and weaned sows for inducing follicle growth, estrogen production, expression of estrus, and ovulation. ${ }^{63,64}$ Specific GnRH analogs have also been tested for use in swine and the analog for GnRH-III (peforelin) given in a single injection 24 hours after weaning showed minimal evidence for stimulating follicle development and improving estrus expression, and was not able to increase FSH. ${ }^{65}$ Another study also showed that while GnRH-III did not induce FSH or LH release, the $\mathrm{GnRH}$ agonist, triptorelin (Gonavet, Veyx-Pharma GmbH, Schwarzenborn, Germany), was shown to induce both FSH and $\mathrm{LH}$ release. ${ }^{66}$

\section{Hormonal control of ovulation}

In pigs with mature follicles, ovulation induction has been achieved using hCG, ${ }^{12} \mathrm{pLH},{ }^{67,68}$ and GnRH and its analogs. ${ }^{58}$ In other species, such as rats, recombinant FSH and LH have 
also been shown to induce ovulation and oocyte maturation similar to hCG. ${ }^{13}$ For each of the hormones and the methods of administration, there are differences in the mechanism of action which could be expected to affect the response. The use of hCG for ovulation induction has been the most widely applied over many years with success in ovulation induction and production of ova for in vitro fertilization with minimal problems associated with fertility. Comparisons among the different hormones and their application is important for practical reasons involving purity, production, safety, cost, effectiveness, and fertility. In cattle, differences in the patterns of progesterone production suggest hCG may be better at inducing corpora lutea formation compared to $\mathrm{GnRH}$ (buserelin) due to the reduced half-life of LH activity (5 hours) compared to hCG (30 hours). ${ }^{69}$ However, in cattle, despite wide variation (1,000-10,000 IU) in the dose of hCG injected, this has been unrelated to the ovarian response. ${ }^{4,69}$ In humans, $10,000 \mathrm{IU}$ of $\mathrm{hCG}^{70}$ is routinely used in ovulation induction protocols, but its use has been associated with hyper ovarian stimulation, and associated with the sustained bioactivity of various isoforms of $\mathrm{hCG}^{71}$ In the pig, the effective dose used for inducing ovulation is 500-1,000 IU of hCG, with the hormone elevated in blood for 24-36 hours following injection. ${ }^{1,12,51}$ Comparison among species for the effects of hCG may be difficult due to the large species differences in follicle development and the hCG dosages applied. However, certain similarities may suggest a common mechanism of action. In humans, hCG and LH bind the same receptor but induce different signaling based on their unique carbohydrate side chains. ${ }^{72}$ In livestock, while hCG is highly effective, concerns about product sourcing, availability, and isoforms suggest that in the future, there could be possible advantages to the usage of synthetic analogs. The discovery and elucidation of the structure of GnRH in the 1970s lead to the synthesis of the decapeptide its agonists and antagonists. ${ }^{73}$ Modification of $\mathrm{GnRH}$ with substitution of an inactive amino acid at position 6 was used to decrease the rate of degradation by endogenous peptidases, while substitution or deletion in amino acid position 10 increased receptor affinity, with the combined effect to increase potency 10-200 times. ${ }^{27}$ However, in humans and some other species, the intent of administration of $\mathrm{GnRH}$ with high potency is often to inhibit gonadotropin release in the long-term, through blocking or downregulation of GnRH receptors. ${ }^{74,75}$

In swine, synthetic GnRH and its analogs have been evaluated and when injected into gilts can induce ovulation, ${ }^{76}$ and a surge of LH that peaks 1-10 hours later, with ovulation starting between 31 and 36 hours after injection and finishing between 35 and 39 hours. $^{77}$ In a review of approaches for ovulation induction, noted individual variation in response of gilts in duration of the LH surge, time from injection to peak LH, and time from start to completion of ovulation was observed. Further, variation in ovulation patterns within an animal showed evidence of some animals ovulating all follicles at once, within 2 hours of each other, or over several hours. While the cause is not clear, this variation could be due to the dose and the hormone used (hCG, gonadorelin, goserelin, buserelin, deslorelin, peforelin, or triptorelin) and the timing of administration relative to follicle maturity. ${ }^{59}$ Early studies in pigs used hCG, GnRH analogs, and even the combination of $\mathrm{hCG}$ and $\mathrm{GnRH}$ to induce ovulation. The average time of ovulation was 37 hours after treatment, with a range of 24-40 hours, and a mean duration of ovulation of 2.5 hours. ${ }^{58}$ In gilts treated with eCG, GnRH given at 80 hours induced ovulation starting at 35 hours and lasted for a duration of 3 hours. ${ }^{1}$ The same type of approach can be applied to groups of gilts synchronized using a progestogen, with GnRH given at 120 hours after last progestogen application. In barrows and gilts, $\mathrm{GnRH}$ agonist treatment (goserelin) was shown to induce an LH surge that peaked 0.5 hours after treatment and returned to baseline within 4 hours. $^{78}$ Other studies reported that prepubertal gilts treated with eCG followed by injection of a GnRH analog 72 hours later induced ovulation in all gilts, while $\mathrm{GnRH}$ given alone without any follicle induction induced only a few ovulations. ${ }^{79}$ Studies testing use of synthetic GnRH in gilts reported that when given at the onset of estrus, $\mathrm{LH}$ was increased as was ovulation rate. ${ }^{80}$ Others tested GnRH (buserelin) and hCG when given at the onset of estrus on day 5 in weaned sows and reported treatment advanced and induced ovulation, but noted that some of the GnRH treated animals developed cysts. ${ }^{81}$ Alternative methods for GnRH administration have been available for many years in humans for medical treatment and control of reproduction and have included injection, nasal spray, slow release capsules, and intravaginal gels. ${ }^{71,73,82}$ Route of administration has been shown to alter the effective dose, and rabbits given a $\mathrm{GnRH}$ analog in the semen for intravaginal absorption, required a $15 \%$ increase for induction of ovulation through the vaginal mucosa. ${ }^{11}$ In pigs, intravaginal administration of a $\mathrm{GnRH}$ analog (triptorelin) was shown to induce an LH surge within 4-16 hours and ovulation within 44 hours following deposition, and which could be altered by changing the viscosity of the carrier gel formulation. ${ }^{83}$ A similar study evaluated administration of GnRH at 96 hours after weaning or at the onset of estrus and reported ovulation tended to be advanced 
when given at 96 hours, but not when given at the onset of estrus. ${ }^{84}$ Subsequent studies with intravaginal administration tested a higher dose and observed that while all GnRH doses advanced ovulation, only the highest dose induced more sows to ovulate within 48 hours after treatment. ${ }^{85}$

The success of exogenous ovulation induction in pigs appears to depend upon the hormone and dose used, the stage of follicle development at time of treatment, and ensuring that treatment occurs prior to the endogenous LH surge. In a study to compare hCG to synthetic GnRH given to sows 72 hours after weaning, differences in the responses were noted. Use of hCG induced smaller follicles to develop and reduced estrus expression, while GnRH induced follicle growth and greater cyst formation. It was reported that administration too early in the stage of follicle development may ovulate more immature follicles, induce cysts, and inhibit estrus expression. ${ }^{86}$ In the pig, this would appear to result from early luteinization of follicle cells in response to $\mathrm{hCG}$, which can be detected by changes in steroid production within 24 hours in vitro and within 48 hours in vivo. ${ }^{87,88} \mathrm{An}$ analogous study tested hCG treatment at 72 or 84 hours after weaning, and while each appeared to have been too early in the stage of follicle maturity, ovulation was advanced in some, but overall group synchrony was poor when compared to delay until 96 hours. ${ }^{85}$ Yet, delaying treatment until time of onset of estrus appears too late, and likely induces an LH surge after the onset of the endogenous LH surge. This appears true since only $50 \%$ of females treated at estrus ovulate within a 38 to 48-hour window, while treatment slightly ahead of the onset of estrus induces ovulation of smaller sized follicles, but with more females ovulating within the window. ${ }^{50}$ This type of ovarian response is supported by a study that delayed administration of GnRH until estrus, and which shortened the duration of estrus, but had minimal effect for advancing or synchronizing ovulation when compared to earlier induction at 96 hours after weaning. ${ }^{84}$

\section{Fertility with Al following induced ovulation}

In pigs, reports of ovulation induction with timed AI have been available for many years. A high proportion of sows treated with hCG at 96 hours following progestogen synchronization with or without eCG ovulated within 48 hours and only failed to ovulate if they had less mature follicles. Further, a single AI performed at 24 hours after hCG resulted in good fertility. ${ }^{10}$ A similar protocol using stimulation of follicle development and estrus, with ovulation induction with hCG 56 or 72 hours later, and followed by a single AI 24 hours later, was also reported to be associated with high pregnancy rates and litter sizes similar to controls. ${ }^{89}$ Numerous other studies have reported fertility outcomes from similar protocols regardless of whether ovulation was directly assessed or not. ${ }^{90}$ Farrowing rates and litter sizes similar to controls inseminated based on estrus were reported when inducing ovulation with 500 or $1,000 \mathrm{IU}$ of hCG at 72 or 96 hours after eCG, and followed by fixed time inseminations 24 and 36 hours after hCG. ${ }^{91}$ Large-scale commercial application using induction of ovulation with fixed time inseminations was implemented in the 1980s to assist East German pig farms address the challenges of increasing farm size, reduced labor availability, and need for improved production flow and management. By 1990, the technology was being used on more than $85 \%$ of the farms. ${ }^{59}$ Considerable data were available to show that different products such as GnRH could improve ovulation synchrony, with groups starting ovulation at 35 hours and completing the process by 40 hours. Reviews of fixed time AI protocols in commercial settings revealed aspects that could affect fertility responses to insemination such as variation in the administration of treatment to start of ovulation. ${ }^{59}$ In studies that used fixed time AI at 24 and 42 hours following ovulation induction, fertility results were acceptable and similar to fertility using conventional inseminations based on estrus at that period of time. ${ }^{58}$ However, the authors reported that fertility responses were affected by lactation length and parity and required adjustment in the timing of hormone administration if eCG was used for follicle induction. The early studies also indicated that replacement of hCG with GnRH could improve fertility. In gilts, synchronized follicle development and estrus expression combined with induction of ovulation and used with various AI times all resulted in good fertility. ${ }^{1}$ Interestingly, the timing of GnRH following the start of the follicle phase had limited effects on ovulation synchrony in gilts, in contrast to sows ${ }^{92}$ and might suggest greater variation in follicle development in sows compared to gilts. A comprehensive review of different follicle stimulation procedures combined with ovulation induction methods and different fixed time AI schedules was recently published.$^{61}$ Hormones such as pLH given to gilts at a fixed time during the follicle phase with AI 32 and 40 hours later ${ }^{93}$ and weaned sows given $\mathrm{pLH}$ at estrus with AI 12 and 32 hours later, ${ }^{67}$ each induced fertility similar to controls. This type of data is also evident with use of $\mathrm{hCG}$ and $\mathrm{GnRH}$ for synchronized gilts, and weaned sows with a variety of ovulation induction times during the follicle phase and various AI times following induction. ${ }^{1,58,61}$ Of interest, is the importance of a double versus a single insemination. 
While this has not been tested directly, there are clear indications that fixed time double inseminations can work ${ }^{1}$ and evidence exists that shows double and single inseminations following induction do not differ from controls inseminated based on estrus. ${ }^{85}$ However, in swine, ovulation induction coupled with application of only a single, fixed time AI has been a goal. A recent study evaluated buserelin given at 86 hours following weaning, with insemination of sows in estrus, 30 hours later. This was done based on previous data showing that the GnRH agonist used induced an LH surge that peaked 24 hours after administration and resulted in ovulation occurring between 32 and 44 hours in $76 \%$ of the animals. The fertility data from the single AI study showed farrowing rate and litter size did not differ from controls. ${ }^{94}$

\section{Changes and challenges to production systems with application for ovulation induction}

The fact that many protocols can be effective for achieving fertility in synchronized gilts and weaned sows using a variety of hormones and timings for ovulation induction and fixed time AI suggests high sensitivity of pig follicles to the LH surge and an extended window of time for sperm fertility following AI. The different approaches appear to work well in many research scenarios, with some tested and shown to be effective for inducing high fertility in commercial settings, ${ }^{94}$ while in other studies, the induced fertility is deemed acceptable or not significantly different from controls. This may be an important distinction as different operations may place priority on matching current farrowing rates and litter size targets, while others may add greater emphasis on additional considerations that may include labor, production flow, and costs. In light of how different farms may value ovulation induction with fixed time AI, the selection of this technology must be practical for on-farm application and must achieve the minimum targets for fertility. For those farms that implement the technology, there will be challenges to success for ovulation induction and timed AI, since not all animals will be at the same physiological stage of follicle maturity at the time of protocol implementation. In weaned sows, considerable variation in follicle development can be assessed through ovarian evaluation of follicle numbers and sizes, measures of estrus, and time of ovulation in relation to farm, season, parity, and lactation length. ${ }^{17,95,96}$ Herds with excessive variation in lactation length and high proportions of parity 1 sows could be expected to show more variation in follicle development and poorer responses to ovulation induction alone. The fact that follicle development and estrus expression can be improved by exogenous gonadotropins like eCG ${ }^{1,58,61}$ and PG600 suggests that their use in scenarios with risk of delayed follicle development could prove advantageous. ${ }^{97,98}$ These hormone treatments are not expected to work in all cases but can generally improve follicle development and estrus expression by $15 \%-20 \%$ in treated sows. Poor follicle development is a leading factor associated with anestrus or delayed estrus expression and poor response to ovulation induction. Estrus expression was reported to be reduced by $12 \%$ when sows had follicle sizes $<6.5 \mathrm{~mm}$ at 96 hours after weaning. ${ }^{84}$ There are other reasons sows and gilts may fail to respond to ovulation induction and fixed time AI, which may include problems of inactive ovaries, cystic follicles, presence of corpora lutea, genitourinary disease, and reproductive tract abnormalities. ${ }^{84,99-101}$ In a protocol using induced ovulation with fixed time AI, each of these fertility problems would likely be associated with protocol failure, but would not be correctly diagnosed as female infertility. One approach to limit these cases of infertility would be to exclude females not expressing estrus at time of $\mathrm{AI},{ }^{94}$ although there is evidence that estrus detection and expression is not required for success with ovulation induction and AI. ${ }^{58,84}$ Diagnosing the reproductive status of the female would be important for determining which animals should receive follicle stimulation, ovulation induction, and insemination and which ones should be excluded from the protocols. The current technology for ultrasound diagnosis of reproductive status could also prove useful, ${ }^{102}$ but its application may be too intensive and therefore perhaps more practical for targeted diagnosis, and not for routine use on all sows or farms. A faster diagnostic test based on indicators for metabolic or reproductive state might be more useful and practical if a simple sampling approach and indicator test could be developed. The costs associated with induction and insemination of infertile females, and costs of feeding for 3-4 weeks, must be weighed against risks for nonresponse and diagnostic tests.

For ovulation induction with fixed time AI to work optimally, several steps must occur: 1) follicle growth and maturation should be synchronized in all females; 2) all females would have mature follicles at time of induction; 3 ) all would have a similar timed LH surge; 4) all follicles would ovulate in a defined window; and 5) sperm would be established in the reservoir before ovulation to fertilize all eggs. To achieve optimal fertility, important considerations should include what types of farms should be enrolled and where should effort be applied to improve the response. The reality may be that follicle synchrony and maturation will at best be $90 \%$, 
with many farms likely to show $80 \%$ for this measure and for all of the other fertility steps. It is also likely that due to variation in follicle sizes among and within females, which suggests differential gonadotropin stimulation or response, the characteristics of the LH surge and response to ovulation may also vary, affecting $10 \%-20 \%$ of females. On the positive side, what appears relatively consistent is the duration of ovulation and the window for sperm fertility. Since ova have a short fertilization life following ovulation, sperm present in the reservoir should be capacitated and ready to fertilize the eggs at time of ovulation. Sperm reservoirs with single inseminations of liquid extended semen are functional for up to 24 hours, ${ }^{103}$ while frozen-thawed sperm has a much shorter window for maximal fertility. ${ }^{104}$ The impact of sperm numbers with use of ovulation induction and fixed time AI may become more critical as the number and quality of the fertile sperm are changed with use of low-dose AI, frozenthawed, and sex-sorted sperm.

\section{Changing the scenario for modern swine breeding}

It appears that conditions are favorable for adoption of induced ovulation with fixed time AI in the pig industry. Since different products and procedures have been shown over many years to be effective in research and commercial settings, the choices of which one to use will involve regulatory approval in each country, ${ }^{1,59}$ costs associated with the hormones, ${ }^{94}$ labor associated with application, and effectiveness in the production system. Various methods have been reviewed for use in gilts and weaned sows and demonstrate the timeline for on-farm scheduling. ${ }^{61}$ The greatest advantages in any production system to control ovulation include the potential for increased genetic gain, improved herd fertility, more consistent production flow, and ability to address the challenges associated with labor and management with increasing farm size.$^{58}$ Control of ovulation will also necessitate making breeding decisions regarding the number and timing of inseminations, the storage form of the sperm, the number of sperm to use, and the site of semen deposition. Use of single sire inseminations for capturing genetic gains and fertility advantages from high indexing boars for pig production has been reported. ${ }^{105}$ Further, single service inseminations will provide the greatest opportunity to capture these advantages from distribution of limited numbers of sperm from these sires. When using induced ovulation, AI with liquid extended semen can utilize a single AI containing anywhere from 0.5 to 2.5 billion sperm. As sperm numbers are reduced, technologies such as intrauterine insemination can prove beneficial for fertility. ${ }^{106-109}$ Single, timed inseminations will also be necessary and will be most practical for use of frozen and sex-sorted sperm due to the costs of their production, the limited numbers of viable sperm, and their reduced in vivo lifespan. ${ }^{110,111}$ These technologies although limited in use remain important for meeting future goals of producing sexed offspring, improving the capability for enhanced disease prevention, and expanding time and distance for gene transfer through semen. With greater use of single-service and low-dose AI, changes will occur in selection and inventory of boars in AI centers. Application of ovulation induction with timed AI will affect sow farms and have dramatic effects on labor associated with major events of breeding and farrowing. With use of induced ovulation with fixed time insemination, the daily labor associated with boar movement and detection of estrus in females is not an essential requirement, and could be reallocated for administration of the induction hormones on specific days, and other farm tasks. Changes in the AI technology from conventional to intrauterine is already progressing, and will likely continue to advance with technological advancements in catheter design that allow more females to be inseminated using uterine deposition techniques.

\section{Disclosure}

The author reports no conflicts of interest in this work.

\section{References}

1. Hühn U, Jöchle W, Brüssow KP. Techniques developed for the control of estrus, ovulation and parturition in the East German pig industry: a review. Theriogenology. 1996;46(6):911-924.

2. Hayden C. GnRH analogues: applications in assisted reproductive techniques. Eur J Endocrinol. 2008;159(Suppl 1):S17-S25.

3. Messinis IE. Ovulation induction: a mini review. Hum Reprod. 2005;20(10):2688-2697.

4. Yavas Y, Wallon JS. Induction of ovulation in postpartum suckled beef cows: a review. Theriogenology. 2000;54(1):1-23.

5. D'Occhio MJ, Fordyce G, Whyte TR, Aspden WJ, Trigg TE. Reproductive responses of cattle to GnRH agonists. Anim Reprod Sci. 2000;60-61:433-442.

6. Filicori M, Cognigni GE, Pocognoli P, et al. Comparison of controlled ovarian stimulation with human menopausal gonadotropin or recombinant follicle-stimulating hormone. Fertil Steril. 2003; 80(2):390.

7. Filicori M. The role of luteinizing hormone in folliculogenesis and ovulation induction. Fertil Steril. 1999;71(3):405-414.

8. Wiltbank MC, Pursley JR. The cow as an induced ovulator: timed AI after synchronization of ovulation. Theriogenology. 2014;81(1):170-185.

9. Gobello C. Effects of GnRH antagonists vs agonists in domestic carnivores, a review. Reprod Dom Anim. 2012;47:373-376.

10. Polge C, Day BN, Groves TW. Synchronization of ovulation and artificial insemination in pigs. Vet Rec. 1968;83:136-142.

11. Quintela LA, Peña AI, Vega MD, et al. Reproductive performance of rabbit does artificially inseminated via intravaginal administration of [des-Gly 10, d-Ala6]-LHRH ethylamide as ovulation inductor. Reprod Dom Anim. 2009;44(5):829-833. 
12. Dziuk PJ, Gehlbach GD. Induction of ovulation and fertilization in the immature gilt. J Anim Sci. 1966;25:410-413.

13. Gómez R, Lima I, Simón C, Pellicer A. Administration of low-dose LH induces ovulation and prevents vascular hyperpermeability and vascular endothelial growth factor expression in superovulated rats. Reproduction. 2004;127(4):483-489.

14. Onagbesan OM, Peddie MJ. Induction of ovulation and oviposition in female quail with luteinizing hormone, luteinizing hormone releasing hormone, or progesterone. Gen Comp Endocrinol. 1988;71(1): 124-131.

15. Guthrie HD, Garrett WM. Apoptosis during folliculogenesis in pigs. Reprod Suppl. 2001;58:17-29.

16. Foxcroft GR, Hunter MG. Basic physiology of follicular maturation in the pig. J Reprod Fertil Suppl. 1985;33:1-19.

17. Lucy MC, Liu J, Boyd CK, Bracken CJ. Ovarian follicular growth in sows. Reprod Suppl. 2001;58:31-45.

18. Ainsworth L, Tsang BK, Downey BR, Marcus GJ. The synthesis and actions of steroids and prostaglandins during follicular maturation in the pig. J Reprod Fertil Suppl. 1990;40:137-150.

19. Noguchi M, Yoshioka K, Itoh S, et al. Peripheral concentrations of inhibin A, ovarian steroids, and gonadotropins associated with follicular development throughout the estrous cycle of the sow. Reproduction. 2010;139(1):153-161.

20. Robertson DM. Inhibins and activins in blood: predictors of female reproductive health? Mol Cell Endocrinol. 2012;359(1-2):78-84.

21. McNeilly AS, Crawford JL, Taragnat C, Nicol L, McNeilly JR. The differential secretion of FSH and LH: regulation through genes, feedback and packaging. Reprod Suppl. 2003;61:463-476.

22. Padmanabhan V, McNeilly A. Is there an FSH-releasing factor? Reproduction. 2001;121(1):21-30.

23. Knox RV, Taibl J, Altmyer M, Breen S, Canaday D, Visconti A. Assessment of follicle population changes in sows from day of weaning and during estrus using real-time ultrasound. Soc Reprod Fertil. 2009;66:199-200.

24. Hunter MG, Grant SA, Foxcroft GR. Histological evidence for heterogeneity in the development of preovulatory pig follicles. J Reprod Fertil. 1989;86:165-170.

25. Hunter MG, Wiesak T. Evidence for and implications of follicular heterogeneity in pigs. J Reprod Fertil Suppl. 1990;40:163-177.

26. Tonetta SA, diZerega GS. Local regulatory factors controlling folliculogenesis in pigs. J Reprod Fertil Suppl. 1990;40:151-161.

27. Casper RF. Basic understanding of gonadotropin-releasing hormoneagonist triggering. Fertil Steril. 2015;103(4):867-869.

28. Kraeling RR, Barb CR. Hypothalamic control of gonadotrophin and prolactin secretion in pigs. J Reprod Fertil Suppl. 1990;40: 3-17.

29. Britt JH, Esbenshade KL, Ziecik AJ. Roles of estradiol and gonadotropin-releasing hormone in controlling negative and positive feedback associated with the luteinizing hormone surge in ovariectomized pigs. Biol Reprod. 1991;45(3):478-485.

30. Estienne MJ, Harter-Dennis JM, Barb CR. Role of neuropeptides and amino acids in controlling secretion of hormones from the anterior pituitary gland in pigs. J Reprod Fertil Suppl. 1997;52:3-17.

31. Beltramo M, Dardente H, Cayla X, Caraty A. Cellular mechanisms and integrative timing of neuroendocrine control of $\mathrm{GnRH}$ secretion by kisspeptin. Mol Cell Endocrinol. 2014;382(1):387-399.

32. Tsutsui K, Ubuka T. Breakthrough in neuroendocrinology by discovering novel neuropeptides and neurosteroids: 1. Discovery of gonadotropin-inhibitory hormone (GnIH) across vertebrates. Gen Comp Endocrinol. 2014;205:4-10.

33. Caraty A, Decourt C, Briant C, Beltramo M. Kisspeptins and the reproductive axis: potential applications to manage reproduction in farm animals. Domest Anim Endocrinol. 2012;43(2):95-102.

34. Lents CA, Heidorn NL, Barb CR, Ford JJ. Central and peripheral administration of kisspeptin activates gonadotropin but not somatotropin secretion in prepubertal gilts. Reproduction. 2008;135(6): $879-887$.
35. Bliss SP, Navratil AM, Xie J, Roberson MS. GnRH signaling, the gonadotrope and endocrine control of fertility. Front Neuroendocrinol. 2010;31(3):322-340.

36. Knox RV, Vatzias G, Naber CH, Zimmerman DR. Plasma gonadotropins and ovarian hormones during the estrous cycle in high compared to low ovulation rate gilts. J Anim Sci. 2003;81(1):249-260.

37. Jayes FC, Britt JH, Esbenshade KL. Role of gonadotropin-releasing hormone pulse frequency in differential regulation of gonadotropins in the gilt. Biol Reprod. 1997;56(4):1012-1019.

38. Thompson IR, Kaiser UB. GnRH pulse frequency-dependent differential regulation of LH and FSH gene expression. Mol Cell Endocrinol. 2014;385(1-2):28-35.

39. Espey LL, Richards JS. Ovulation. In: Neill JD, editor. Knobil and Neill's Physiology of Reproduction. Vol 1. 3rd ed. St Louis, MO: Elsevier; 2006:425-474.

40. Lipner H. Mechanisms of mammalian ovulation. In: Knobil E, Neill J, editors. The Physiology of Reproduction. Vol 1. New York, NY: Raven Press Ltd; 1988:447-488.

41. Kim J, Bagchi IC, Bagchi MK. Control of ovulation in mice by progesterone receptor-regulated gene networks. Mol Hum Reprod. 2009; 15(12):821-828.

42. Conneely O. Progesterone receptors and ovulation. In: Habenicht U-F, Aitken RJ, editors. Fertility Control. Vol 198. Berlin, Heidelberg: Springer; 2010:37-44.

43. Richards JS, Pangas SA. The ovary: basic biology and clinical implications. J Clin Invest. 2010;120(4):963-972.

44. Soede NM, Helmond FA, Kemp B. Periovulatory profiles of oestradiol, $\mathrm{LH}$ and progesterone in relation to oestrus and embryo mortality in multiparous sows using transrectal ultrasonography to detect ovulation. J Reprod Fertil. 1994;101(3):633-641.

45. Jonas HA, Burger HG, Cumming IA, Findlay JK, De Kretser DM. Radioimmunoassay for luteinizing hormone-releasing hormone (LHRH): its application to the measurement of LHRH in ovine and human plasma. Endocrinology. 1975;96(2):384-393.

46. Schillo KK, Leshin LS, Kuehl D, Jackson GL. Simultaneous measurement of luteinizing hormone-releasing hormone and luteinizing hormone during estradiol-induced luteinizing hormone surges in the ovariectomized ewe. Biol Reprod. 1985;33(3):644-652.

47. Ziecik A, Tilton JE, Espana F, Weigl R. Effect of human chorionic gonadotropin on preovulatory luteinizing hormone surge and ovarian hormone secretion in gilts. J Anim Sci. 1987;64(4):1134-1143.

48. Tilton JE, Foxcroft GR, Ziecik AJ, Coombs SL, Williams GL. Time of the preovulatory LH surge in the gilt and sow relative to the onset of behavioral estrus. Theriogenology. 1982;18(2):227-236.

49. Pope WF, Xie S, Broermann DM, Nephew KP. Causes and consequences of early embryonic diversity in pigs. In: Cole DJA, Foxcroft GR, Weir BJ, editors. Control of Pig Reproduction III. Cambridge, UK: Journals of Reproduction and Fertility Ltd; 1990:251-260.

50. Nissen AK, Schmidt M, Hyttel P, Greve T. Ovulation and embryonic developmental rate following hCG-stimulation in sows. Acta Vet Scand. 2000;41:321-328.

51. Bolamba D, Matton P, Sirard MA, Estrada R, Dufour JJ. Ovarian morphological conditions and the effect of injection of human chorionic gonadotropin on ovulation rates in prepuberal gilts with two morphologically different ovarian types. J Anim Sci. 1991;69(9):3774-3779.

52. Soede NM, Hazeleger W, Kemp B. Follicle size and the process of ovulation in sows as studied with ultrasound. Reprod Dom Anim. 1998;33:239-244.

53. Knox RV. Recruitment and selection of ovarian follicles for determination of ovulation rate in the pig. Domest Anim Endocrinol. 2005;29:385-397.

54. Guthrie HD, Henricks DM, Handlin DL. Plasma hormone levels and fertility in pigs induced to superovulate with PMSG. J Reprod Fertil. 1974;41:361-370.

55. Schilling E, Cerne F. Induction and synchronization of estrus in prepuberal gilts and anestrous sows by a PMS/hCG-compound. Vet Rec. 1972;91(20):471-474. 
56. Breen SM, Knox RV. The impact of dose of FSH (Folltropin) containing LH (Lutropin) on follicular development, estrus and ovulation responses in prepubertal gilts. Anim Reprod Sci. 2012;132(3-4):193-200.

57. Bolamba D, Matton P, Estrada R, Dufour JJ. Effects of pregnant mare's serum gonadotropin treatment on follicular populations and ovulation rates in prepuberal gilts with two morphologically different ovarian types. J Anim Sci. 1992;70(6):1916-1922.

58. Brüssow KP, Jöchle W, Hühn U. Control of ovulation with a GnRH analog in gilts and sows. Theriogenology. 1996;46(6):925-934.

59. Brüssow KP, Schneider F, Kanitz W, Ratky J, Kauffold J, Wahner M. Studies on fixed-time ovulation induction in the pig. Soc Reprod Fertil Suppl. 2009;66:187-195.

60. Bennett-Steward K, Aramini J, Pelland C, Friendship R. Equine chorionic gonadotrophin and porcine luteinizing hormone to shorten and synchronize the wean-to-breed interval among parity-one and parity-two sows. J Swine Health Prod. 2008;16:182-187.

61. Driancourt MA. Fixed time artifical insemination in gilts and sows: tools, schedules and efficicacy. In: Rodriguez-Martinez H, Soede NM, Flowers WL, editors. Control of Pig Reproduction IX. Leicestershire, UK: Context Products Ltd; 2013:89-100.

62. Lutz JB, Rampacek GB, Kraeling RR. Induction of ovulation in the prepuberal gilt by pulsatile administration of gonadotropin releasing hormone. Domest Anim Endocrinol. 1985;2:61-65.

63. Armstrong JD, Britt JH. Pulsatile administration of gonadotropinreleasing hormone to anestrous sows: endocrine changes associated with GnRH-induced and spontaneous estrus. Biol Reprod. 1985;33(2): 375-380.

64. Britt JH, Armstrong JD, Cox NM, Esbenshade KL. Control of follicular development during and after lactation in sows. J Reprod Fertil Suppl. 1985;33:37-54.

65. de Jong E, Kauffold J, Engl S, Jourquin J, Maes D. Effect of a GnRH analogue (Maprelin) on the reproductive performance of gilts and sows. Theriogenology. 2013;80(8):870-877.

66. Brüssow K-P, Schneider F, Tuchscherer A, Kanitz W. Influence of synthetic lamprey GnRH-III on gonadotropin release and steroid hormone levels in gilts. Theriogenology. 2010;74(9):1570-1578.

67. Bennett-Steward K, Cassar G, Plante C. Ovulation induction protocol using equine chorionic gonadotropin and porcine luteinizing hormone in the weaned sow. J Swine Health Prod. 2007;15(4):194-197.

68. Gama RD, Vianna WL, Pinese ME, Rosseto AC, Moretti AS. Different doses of porcine luteinizing hormone in precocious puberty induction in gilts. Reprod Dom Anim. 2005;40(5):433-435.

69. De Rensis F, López-Gatius F, García-Ispierto I, Techakumpu M. Clinical use of human chorionic gonadotropin in dairy cows: an update. Theriogenology. 2010;73(8):1001-1008.

70. Patil M. Gonadotrophins: the future. J Hum Reprod Sci. 2014;7(4): 236-248

71. Fournier T, Guibourdenche J, Evain-Brion D. Review: hCGs: different sources of production, different glycoforms and functions. Placenta 2015;36(Suppl 1):S60-S65.

72. Choi J, Smitz J. Luteinizing hormone and human chorionic gonadotropin: origins of difference. Mol Cell Endocrinol. 2014; 383(1-2):203-213.

73. Mezo G. Peptide and protein based pharmaceuticals. In: Farkas E, Ryadnov M, editors. Amino Acids, Peptides and Proteins. Vol 38. Cambridge, UK: The Royal Society of Chemistry; 2013:203-252.

74. Kumar P, Sharma A. Gonadotropin-releasing hormone analogs: understanding advantages and limitations. J Hum Reprod Sci. 2014;7(3):170-174.

75. Maenhoudt C, Santos NR, Fontbonne A. Suppression of fertility in adult dogs. Reprod Dom Anim. 2014;49:58-63.

76. Webel SK. Ovulation control in the pig. In: Crighton DB, Foxcroft GR, Haynes NB, Lamming GE, editors. Control of Ovulation. London, UK: Butterworths; 1978:421-434.

77. Brüssow KP, Ratky J, Kanitz W, Becker F. The relationship between the surge of LH induced by exogenous Gn-RH and the duration of ovulation in gilts. Reprod Domest Anim. 1990;25:255-260.
78. Brüssow KP, Schneider F, Tuchscherer A, Ratky J, Kraeling RR, Kanitz W. Luteinizing hormone release after administration of the gonadotropin-releasing hormone agonist Fertilan (goserelin) for synchronization of ovulation in pigs. J Anim Sci. 2007;85(1):129-137.

79. Guthrie HD. Induction of ovulation and fertility in prepuberal gilts J Anim Sci. 1977;45(6):1360-1367.

80. Archibong AE, England DC, Stormshak F. Ovulation and embryonic survival in pubertal gilts treated with gonadotropin releasing hormone. J Anim Sci. 1987;65(3):752-755.

81. Wongkaweewit K, Prommachart P, Raksasub R, et al. Effect of the administration of $\mathrm{GnRH}$ or $\mathrm{hCG}$ on time of ovulation and the onset of estrus-to-ovulation interval in sows in Thailand. Trop Anim Health Prod. 2012;44(3):467-470.

82. Sandow J, Stoeckemann K, Jerabek-Sandow G. Pharmacokinetics and endocrine effects of slow release formulations of LHRH analogues. J Steroid Biochem Mol Biol. 1990;37(6):925-931.

83. Stewart KR, Flowers WL, Rampacek GB, Greger DL, Swanson ME, Hafs HD. Endocrine, ovulatory and reproductive characteristics of sows treated with an intravaginal GnRH agonist. Anim Reprod Sci. 2010;120(1-4):112-119.

84. Knox RV, Willenburg KL, Rodriguez-Zas SL, Greger DL, Hafs HD, Swanson ME. Synchronization of ovulation and fertility in weaned sows treated with intravaginal triptorelin is influenced by timing of administration and follicle size. Theriogenology. 2011;75(2):308-319.

85. Knox RV, Taibl JN, Breen SM, Swanson ME, Webel SK. Effects of altering the dose and timing of triptorelin when given as an intravaginal gel for advancing and synchronizing ovulation in weaned sows. Theriogenology. 2014;82(3):379-386.

86. Nissen AK, Lehn-Jensen H, Hyttel P, Greve T. Follicular development and ovulation in sows: effect of hCG and GnRH treatment. Acta Vet Scand. 1995;36:123-133.

87. Downey BR, Draincourt MA. Morphological and functional characteristics of preovulatory follicles in large white and Meishan gilts. J Anim Sci. 1994;72(8):2099-2106.

88. Hunter MG, Picton HM, Biggs C, Mann GE, McNeilly AS, Foxcroft GR. Periovulatory endocrinology in high ovulating Meishan sows. J Endocrinol. 1996;150(1):141-147.

89. Christenson RK, Teague HS. Synchronization of ovulation and artificial insemination of sows after lactation. J Anim Sci. 1975;41(2) 560-563.

90. Callaghan B, King GJ. Induced ovulation and synchronized breeding of prepuberal gilts Can Vet J. 1978;19:90-94.

91. Hodson HH, Hausler CL, Snyder DH, Wilkens MA, Arthur RD. Effect of gonadotropin dose and postpartum status on induced ovulation and pregnancy in lactating sows. J Anim Sci. 1981;52(4):688-695.

92. Martinat-Botté F, Venturi E, Guillouet P, Driancourt MA, Terqui M. Induction and synchronization of ovulations of nulliparous and multiparous sows with an injection of gonadotropin-releasing hormone agonist (Receptal). Theriogenology. 2010;73(3):332-342.

93. Degenstein KL, O’Donoghue R, Patterson JL, et al. Synchronization of ovulation in cyclic gilts with porcine luteinizing hormone $(\mathrm{pLH})$ and its effects on reproductive function. Theriogenology. 2008;70(7): 1075-1085.

94. Driancourt MA, Cox P, Rubion S, Harnois-Milon G, Kemp B, Soede NM. Induction of an LH surge and ovulation by buserelin (as Receptal) allows breeding of weaned sows with a single fixed-time insemination. Theriogenology. 2013;80:391-399.

95. Belstra BA, Flowers WL, See MT. Factors affecting temporal relationships between estrus and ovulation in commercial sow farms. Anim Reprod Sci. 2004;84(3-4):377.

96. Knox RV, Rodriguez-Zas SL. Factors influencing estrus and ovulation in weaned sows as determined by transrectal ultrasound. J Anim Sci. 2001;79(12):2957-2963.

97. Knox RV, Rodriguez-Zas SL, Miller GM, Willenburg KL, Robb JA. Administration of P.G. 600 to sows at weaning and the time of ovulation as determined by transrectal ultrasound. J Anim Sci. 2001;79(4) 796-802. 
98. Bates RO, Day BN, Britt JH, Clark LK, Brauer MA. Reproductive performance of sows treated with a combination of pregnant mare's serum gonadotropin and human chorionic gonadotropin at weaning in the summer. J Anim Sci. 1991;69(3):894-898.

99. Glossop C. Infertility of the gilt and sow. In: Noakes DE, Parkinson TJ, England GCW, editors. Arthur's Veterinary Reproduction and Obstetrics. 8th ed. St Louis, MO: W.B. Saunders; 2001: 621-638.

100. Almond GW. Clinical examination of female reproductive organs. In: Youngquist RS, Threlfall WR, editors. Current Therapy in Large Animal Theriogenology. 2nd ed. St Louis, MO: Saunders Elsevier Inc.; 2007:749-756.

101. Almond GW. Infertility associated with abnormalities of the estrous cycle and the ovaries. In: Youngquist RS, Threlfall WR, editors. Current Therapy in Large Animal Theriogenology. 2nd ed. St Louis, MO: Saunders Elsevier Inc.; 2007:773-777.

102. Kauffold J, Althouse GC. An update on the use of B-mode ultrasonography in female pig reproduction. Theriogenology. 2007;67(5): 901-911.

103. Soede NM, Wetzels CC, Zondag W, de Koning MA, Kemp B. Effects of time of insemination relative to ovulation, as determined by ultrasonography, on fertilization rate and accessory sperm count in sows. J Reprod Fertil. 1995;104(1):99-106.
104. Waberski D, Weitze KF, Gleumes T, Schwartz M, Willmen T, Petzoldt R. Effect of time of insemination relative to ovulation on fertility with liquid and frozen boar semen. Theriogenology. 1994;42:831-840.

105. Foxcroft GR, Dyck MK, Ruiz-Sanchez A, Novak S, Dixon WT. Identifying useable semen. Theriogenology. 2008;70(8):1324-1336.

106. Watson PF, Behan JR. Intrauterine insemination of sows with reduced sperm numbers: results of a commercially based field trial. Theriogenology. 2002;57:1683-1693.

107. Mezalira A, Dallanora D, Bernardi M, Wentz I, Bortolozzo FP. Influence of sperm cell dose and post-insemination backflow on reproductive performance of intrauterine inseminated sows. Reprod Domest Anim. 2005;40(1):1-5.

108. Sbardella PE, Ulguim RR, Fontana DL, et al. The post-cervical insemination does not impair the reproductive performance of primiparous sows. Reprod Dom Anim. 2014;49(1):59-64.

109. Rozeboom KJ, Reicks DL, Wilson ME. The reproductive performance and factors affecting on-farm application of low-dose intrauterine deposit of semen in sows. J Anim Sci. 2004;82(7):2164-2168.

110. Johnson LA, Rath D, Vazquez JM, Maxwell WM, Dobrinsky JR. Preselection of sex of offspring in swine for production: current status of the process and its application. Theriogenology. 2005;63(2):615-624.

111. Johnson LA, Weitze KF, Fiser P, Maxwell WM. Storage of boar semen. Anim Reprod Sci. 2000;62(1-3):143-172.
Veterinary Medicine: Research and Reports

\section{Publish your work in this journal}

Veterinary Medicine: Research and Reports is an international, peer-reviewed, open access journal publishing original research, case reports, editorials, reviews and commentaries on all areas of veterinary medicine. The manuscript management system is completely online and includes a very quick and fair peer-review system.

\section{Dovepress}

Visit http://www.dovepress.com/testimonials.php to read real quotes from published authors. 